\title{
Developmental Patterns in the Interlanguage Research
}

\author{
Antonija Saric \\ Josip Juraj Strossmayer University of Osijek, \\ Faculty of Food Technology Osijek, Kuhaceva 18, 31000 Osijek, Croatia
}

\begin{abstract}
Interlanguage, defined as a dynamic language system created by the second language learners, can be studied by observing how the language of the learner develops over time. It is argued that interlanguage develops in a regular, predictable way. The regularity of interlanguage development can be confirmed by studying the order or the sequence of the acquisition of a certain structure. The former is studied by choosing one of the grammatical structures (i.e. plural-s), followed by collecting interlanguage samples to determine how often a certain structure is used and finally ranking the structure according to accuracy criteria. The latter deals with the detailed investigation of a certain feature (i.e. interrogatives) to show the sequence of stages through which a learner passes in his/her attempt to arrive at the target language. By studying syntactic structures, such as negatives and interrogatives, the regularities of the acquisition stages are most evident. The regularities have been found across many languages, in particular, English and German. To demonstrate that German language develops in a regular fashion, Processability Theory was proposed stating that $L 2$ learners can produce only those L2 structures which they can process at any given point in time emphasizing thus the fact that developmental stages cannot be skipped. Furthermore, developmental patters can also be studied by applying obligatory occasion, target-like or frequency analysis. Both obligatory occasion and target-like analysis compare the learner's and the target language, whereas frequency analysis lists various linguistic devices used by the learner to express a certain grammatical structure and then shows the frequency of using a certain linguistic device.
\end{abstract}

Keywords: developmental patterns, order of acquisition, sequence of acquisition, Processability Theory, frequency analysis, obligatory occasion analysis, target-like analysis

\section{Introduction}

Interlanguage is a theoretical construct, empirically confirmed, created as a result of a cognitive approach to languages where primary importance is given to the internal cognitive processes of a learner, and his/her active contribution to the process of learning which results in different learning strategies. Latent language structures (Lenneberg, 1967) and latent psychological structures (Selinker, 1972), activated when one attempts to learn a second language, determine the interlanguage path. In the past, interlanguage was studied by analysing errors a learner makes at a certain point in time. Since error analysis failed to provide a complete interlanguage picture, because the focus was only on counting and detecting errors, a need to show the development of interlanguage over time was recognized. As interlanguages show deviances in a structured way, they are determined by the rules which can be predicted in advance. The systematic nature of interlanguage can be thus studied by following developmental patterns applying obligatory occasion, target-like, frequency or emergence analysis. Emergence analysis, proposed by Pienemann (1998), reveals that structures emerge in a predicted way and that developmental stages cannot be skipped. It is therefore important to introduce teachers to the notion of interlanguage due to the fact that they are then able to understand better the process of learning, and the fact that the stages of acquisition cannot be skipped through formal education. Instruction is thus only helpful if it focuses on structures from the next stage. 


\section{Interlanguage research}

Error analysis, one of the methods of studying interlanguage, was popular in the 1970s when the focus was on counting and classifying errors and the attempts were made to correct them as it was believed that learners would make progress if they are aware of their errors. Corder (1967) emphasized the importance of errors because they show insight into the way of learning and acquiring the language and display strategies a learner uses on his/her way of discovering the language. Although error analysis received criticism, as it showed very static insight into the way a language is acquired, errors are still taken into account when describing the learner's interlanguage. Common European Framework of Reference for Languages (CEFL) still describes requirements for grammatical accuracy with a constant emphasis on the number and a type of errors neglecting thus the development of grammar (Pallotti, 2010). In order to move away from counting errors, Pienemann (1998) proposes factorization as a way of dissolving different factors bundled together in the second language which can lead to errors. A learner may create an interlanguage system where just one of such factors governs a set of form-function associations and they should be described separately, regardless of the fact that they form structures not allowed by the second language rules. For example, in German language adjectives may be inflected based on a variety of factors, such as number, gender, case. A learner who connects one inflectional morpheme with one of these factors will produce a lot of non-target language forms, but will still follow a specific interlanguage rule.

Furthermore, complete picture of learner's interlanguage can be obtained by studying the way language is used in communication. Pragmatics focuses on what is being said in a particular moment and how it is said. Most of the works so far have focused on the analysis of specific illocutionary acts. The learners have to learn when it is appropriate to use a certain structure and how to encode it, which may lead to various problems. Sociopragmatic failure may be distinguished from pragmalinguistic failure. The former happens when learners display socially inappropriate behavior and the latter happens when learners do not express themselves in a linguistically appropriate way (Thomas, 1983 in Ellis, 1994).

Learner's interlanguage can also be described by observing how learners change their language depending on the occasion. Variability of the learner's interlanguage is mostly systematic because learners change their linguistic forms based on a different linguistic or situational context. It is likely that learners will use target-like forms in formal environment, while their own forms, susceptible to changes, will be used in informal environment. Tarone (1983) has attempted to explain systematic variability by suggesting that second language learners have a series of overlapping mental grammars, which correspond to different contexts in which the second language is used. At one extreme learners have a grammar for informal or vernacular second language use (e.g. in spontaneous casual conversation). At the other extreme learners have a grammar for formal or careful use of the second language (e.g. in writing or classroom use of the second language). Between these extremes, there are mental grammars for different levels of formality of use. Tarone (1983) refers to this set of overlapping styles as the interlanguage capability continuum. Learners acquire grammars on the continuum through exposure to the second language in contexts of different levels of formality. Non-systematic variability is thus created when new forms are received, but are still not a part of the learner's form-function system. Systematic variability is created when new forms are accepted from the learner's existing form-function system. Ortega (2014) emphasizes two approaches to the analysis of interlanguage variability: socio-linguistic approach to variability (Berdan, 1996 in Ortega, 2014) and dynamic approach (Verspoor et al, 2008 in Ortega, 2014). The analysis of negation in English has shown that in any analysis that seeks to explain temporality there is a risk of finding random variability which cannot be traced and, therefore, evidence of learning is missing. On the other hand, the dynamic system perspective has shown that individual ways of acquiring language are still not known and their development might be missed if variability is ignored. The study of this kind of variability is qualitative and can only be conducted over time on an individual basis. Ortega (2014) states that variability studies that focused on the acquisition of negation lack wider socio-linguistic level, proposed by Tarone and Liu (1995 in Ortega, 2014), which includes variability originating from social interactions.

\subsection{Developmental patterns in the interlanguage research}

Since error analysis was abandoned due to the fact that interlanguage was observed as a collection of errors, the need to study the whole process of creating interlanguage at different stages of development was recognized. The conclusion that interlanguage develops in a regular, predictable way was reached. The universal criteria that researches have used in constituting evidence for developmental patterns are the following (Ellis, 1994): 
- $\quad$ The existence of developmental patterns can be determined by studying the order of acquisition of different second language structures or by following sequence of stages through which a learner passes on his/her way of mastering the second language. When studying the order of acquisition, a researcher determines grammatical structures that will be the object of the research (i.e. auxiliary be, plural-s), then he/she collects samples of the learner's interlanguage to determine how often a specific structure is used by different learners and finally structures are ranked according to accuracy criteria. When observing sequence of stages, very often the so called U-shaped behavior can be noticed. For instance, in the beginning, the learners are unable to mark Past Simple of the verb to eat; then they start using correct form of the verb to eat, i.e. ate. Afterwards, the learners overgeneralize the rules for Past Simple Tense, i.e. the form eated is used and finally they go back to the correct form of the Past Simple Tense of the aforementioned verb (Ellis, 1997).

- When describing transitional structures, a developmental stage is said to consist of a period during which learners systematically use a particular form or structure, even though it does not exclude the usage of other forms or structures.

- $\quad$ The forms and structures used by learners at different time periods during the process of second language acquisition can be ordered in a way that one form or structure always precedes another.

- $\quad$ By acquiring some forms or structures of a target language earlier and some later, learners progress step by step along an order or a sequence of acquisition.

- $\quad$ Strong evidence for developmental patterns appear when it is possible to show that an order or a sequence of acquisition is universal (can be applied to different second languages and to all learners). Weak evidence can be found when an order or a sequence of acquisition is only applied to specific languages or specific groups of learners.

Pallotti (2010) emphasizes the fact that studies of acquisition orders should set explicit acquisition criteria that clearly show which conditions should be met to conclude that a specific structure is acquired.

Lowie \& Verspoor (2015) advocate a dynamic explanation where each step of the development can be ascribed to the dynamic interaction of all processes included in the development, whereby the dynamic process cannot be predicted in advance and it is not invariable. Furthermore, they state that developmental stage studies try to reach conclusions which are applicable on a group, but are insignificant on an individual level. If the obtained results are to be applied on a large population of learners, group studies with representative samples using Gaussian statistics based on the normal distribution should be conducted. However, if we want to follow the development of an individual as a result of changing variables in a variable context, longitudinal studies and nonlinear methods of analysis should be applied (Lowie \& Verspoor, 2015).

\subsection{Methods of investigating developmental patterns}

There are various methods which can be used when investigating developmental patterns. One of the methods is to study errors made by the learners and to determine if they change and how they change over time. Furthermore, developmental patterns can also be studied by collecting samples of the learner's language over a period of time in order to determine which linguistic feature emerges and when in the learner's language. According to this approach, acquisition is defined as first occurrence (Wells, 1985). This method is common for the first language acquisition research, but is also proposed as a method of investigating second language acquisition (Pienemann, 1984).

The usual method for the description of developmental patterns is obligatory occasion analysis. The method was clearly described by Brown (1973), and the procedure is as follows: first, samples of a learner language are collected in the natural environment; second, obligatory occasions for the use of specific target language forms are identified. While using the second language, learners create occasions in which it is necessary to use a specific form of the target language, even though they do not always use it correctly. For instance, a learner can say utterances such as I watched a good film yesterday and $\mathrm{He}$ come late for the show yesterday*. In both sentences, an occasion for the usage of Past Simple was created, although a learner has made a mistake in the second sentence. Afterwards, the percentage of accurate use of a specific form is calculated in order to determine if the needed form is used in all required contexts. Finally, level of accuracy of a specific form is determined. The level is usually set at $80-90 \%$ considering the fact that not even native speakers are able to provide all correct forms. According to Brown (1973), if a certain structure is acquired, it will be a constant part of the learner's interlanguage system, even at higher developmental stages. Vainikka \& Young-Scholten (1994, in Pallotti, 
2007) consider a certain structure acquired if it is correctly used in $60 \%$ of the cases, Ellis (1988, in Pallotti, 2007) requires $75 \%$ accuracy, Andersen (1978, in Pallotti, 2007) $80 \%$, and Dulay \& Burt (1974) set the accuracy level at $90 \%$. The problem which emerges when using this method is that it takes no account of when the same form is used in a non-obligatory context. For example, a learner overgeneralizes Past Simple in the sentence I watched a good film yesterday and now I remembered all details from the film because he/she uses Past Simple in both cases. A procedure called target-like use analysis was proposed as a way of dealing with the overgeneralization and incorrect usage of a certain form. Pica (1983) reached a conclusion that relevant differences in the assessment of a learner's ability depend on whether an obligatory occasion or a target-like use analysis is employed. Both methods compare the learner's interlanguage with the target language. Bley-Vroman (1983) warned that it may lead to comparative fallacy which could appear if the fact that learners form their own rule systems in the process of acquiring second language is neglected. Selinker (2014) talks about deep interlanguage semantics as a way of dealing with comparative fallacy. ${ }^{1}$ Target-like use analysis cannot be used for the description of a system that is created by the learners in the process of learning, since it only provides information up to which level the learner's interlanguage has come closer to the target language. Another problem is the question of the target language norm that should be followed as a basis for the comparison of the learner's language. Norms also differ according to different dialogues spoken in the target language community, and it is difficult to determine if all the target language learners want to follow the standard dialect.

One of the ways of overcoming these problems is to list various linguistic devices used by the learners in order to express a specific grammatical structure (such as questions) and then to calculate the frequency of usage of a specific device at different points in the learners' development (Cazden et al, 1975, as cited in Ellis, 1994). This method is called frequency analysis and it is very useful in disclosing vertical variations in the interlanguage development. By applying this method it is possible to show the prominence of different elements at different developmental stages. Many of the above mentioned studies are longitudinal, i.e. the data are collected over the period of a few months or years. On the other hand, there are cross-sectional studies which are used to collect the data at a single point in time. The method often applied in crosssectional studies is implicational scaling which focuses on the changes in the learner's interlanguage in order to find out which form different learners have acquired and to arrange specific forms into a hierarchy (Decamp, 1971).

\subsubsection{Processability Theory (PT)}

For the analysis of the learner's interlanguage, Pienemann (1998) uses emergence analysis in order to describe the beginning in the process of the acquisition of a specific structure in oral production. First, data are collected using oral interviews with the interlocutor. In order to exclude formulae, Pienemann (1998) proposes checking of lexical/grammatical variations (for example, usage of the same morpheme with different words and the same word with different morphemes). Interpretation of the collected data depends on acquisition criteria being used. Pienemann (1998) states that accuracy criteria are arbitrary. Figure 1 shows different developmental trajectories of specific grammatical structures, i.e. different learners will use differently the same grammatical structure in an obligatory context. Obviously, three different paths have different gradients. The order of acquisition can thus be $c>b>a$ using a $50 \%$ criterion or $c>a>b$ using a $100 \%$ criterion. Pienenemann (1998) therefore proposed the emergence criterion which is not arbitrary. The first step of the emergence analysis is distributional analysis or qualitative representation of different structures in a sample which keeps track of the frequency of tokens and determines if a specific form is mapped onto specific structure. The second step is separation of productive forms from formulae. Productivity is measured by the number of tokens and the systematic use of lexical/morphological varieties of these tokens. The third step of the emergence analysis is implicational scaling; each rule is presented in the form of a developmental stage, that is, a rule formed later implies the presence of the earlier acquired rules.

\footnotetext{
${ }^{1}$ Selinker (2014) advocates the notion of searching for universal and idiosyncratic interlanguage logical propositions, explained within a deep interlanguage semantics.
} 


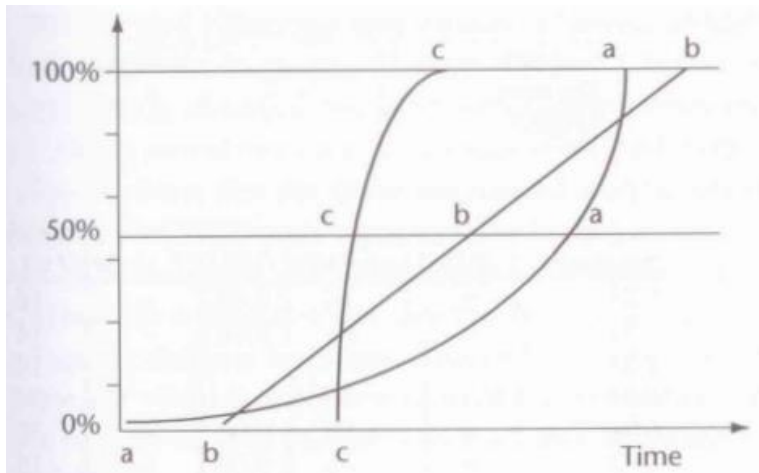

Figure 1. Accuracy and developmental trajectories. "Processability theory" by M. Pienemann and J-U. Keßler, 2012. p. 237.

The core of the PT lies in the fact that learners can produce only those forms which they can process at any given point in time, which means that they cannot be taught structures from higher developmental stages that cannot be processed by their language processor. Pienemann (1998) claims that English morphology and syntax develop in six stages presented in Table 1.

Table 1. Developmental stages for English morphology and syntax (Pienemann, 2005b, p. 24)

\begin{tabular}{|c|c|c|c|c|}
\hline Stage & Processing Procedure & L2 process & Morphology & Syntax \\
\hline 6 & Subordinate clause procedure & $\begin{array}{l}\text { Main and subordinate } \\
\text { clause }\end{array}$ & & Cancel inversion \\
\hline 5 & Sentence procedure & $\begin{array}{l}\text { Inter-phrasal } \\
\text { agreement }\end{array}$ & $\begin{array}{l}\text { Subject-Verb agreement } \\
\left(3^{\text {rd }} \text { person singular }-s\right)\end{array}$ & Do2nd, Aux2nd \\
\hline 4 & Verb phrase procedure & $\begin{array}{l}\text { Inter-phrasal } \\
\text { agreement }\end{array}$ & Tense agreement & $\begin{array}{l}\text { Y/N inversion, copula } \\
\text { inversion }\end{array}$ \\
\hline 3 & Noun phrase procedure & Phrasal information & $\begin{array}{l}\text { Noun phrase } \\
\text { agreement, } \\
\text { Negation+Verb }\end{array}$ & $\begin{array}{l}\text { Adverb fronting, Do- } \\
\text { fronting }\end{array}$ \\
\hline 2 & Category procedure & $\begin{array}{l}\text { Lexical morphology } \\
\text { Possessive pronouns }\end{array}$ & Plural & Canonical word order \\
\hline 1 & Word/lemma & Noun procedure & Invariant forms & Single constituents \\
\hline
\end{tabular}

The elements presented in Table 1 form a hierarchy; the element of a lower stage is a prerequisite for other elements of higher stages, making it impossible for the stages to be skipped. Although the acquisition path can be predicted in advance, as it includes developmental stages, there is a variable dimension which accounts for the individual differences between two different developmental trajectories presented in Figure 2. Two different developmental trajectories are based on developmental stages (marked with the dotted horizontal lines), while the differences are observable in different interlanguage varieties which are developed at each stage (marked with vertical lines in Figure 2). It is important to note that for every process of learning there is a limited number of variable solutions. During second language development, the learner accumulates grammatical rules and their variations which help him/her to develop his/her own developmental path while at the same time adhering to the general developmental order. In that way, two-dimensional space for the formation of a certain hypothesis is defined within the PT. Both dimensions of this space are constrained by the processing hierarchy which can be applied to any other language. 


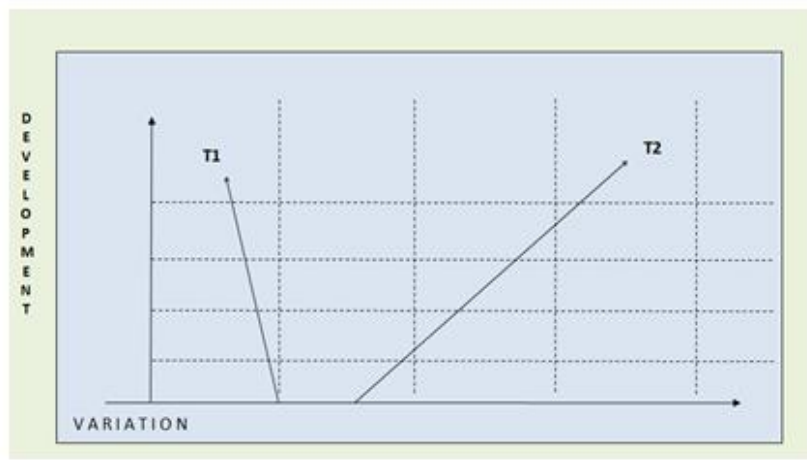

Figure 2. Two different developmental trajectories. "Processability theory" by M. Pienemann and J-U. Keßler, 2012. p. 230 .

According to the PT, all the variable solutions used by the learner are located within language processing, which means that the PT contains two dimensions: development of processing capacity and individual variations chosen by the learner as a solution for each stage. Those dimensions are shown in Figure 3.

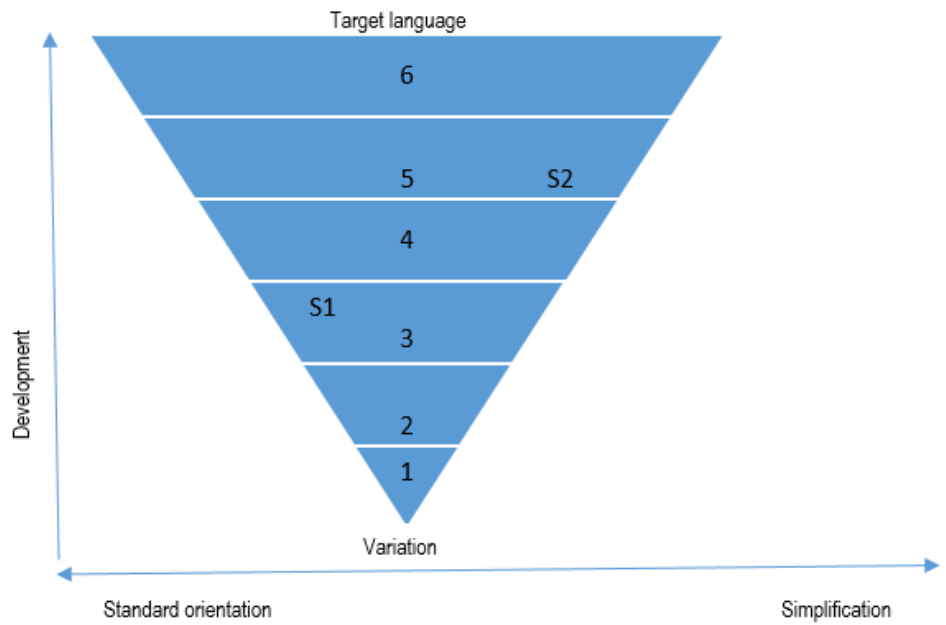

Figure 3. Hypothesis Space. "Studying Processability theory: An introductory textbook" by M. Pienemann and J-U Keßler, 2011, p. 38.

Figure 3 shows development stages vertically and variable solutions horizontally. S1 and S2 in the Figure represent the learner's possible grammars. The variation shows simplifications of solutions on the right and the standard oriented solutions on the left. Considering that Hypothesis Space enables a unique, individual developmental path determined by the chosen solutions that the learner finds in each stage within the entire system, it is possible to show the dynamics of interlanguage grammars and its development (Pienemann, 2005b). Variable solutions chosen by the learner at each level of development have an effect on a later development, considering that the learner's choices accumulate along with the development of the learner's interlanguage. According to Pienemann (1998) learner's interlanguage stabilizes if the learner makes a large number of bad choices. Also, it is not simple for second language learners to make the shift from simplification to using standard orientation and vice versa. 
Pienemann (1998) also states that despite the permanent hierarchy of processing, the learners will develop their own interlanguage; he also explains that the variations between learners and different final outcomes are due to differences in their development dynamics. The generative entrenchment model ${ }^{1}$ influenced the construction of development dynamics in the PT. Pienemann (1998) understands development as a process in which the development of more complex structures happens gradually, beginning with the lowest number of structural properties, to which other properties are added through development (Figure 4). The key explanation of this model resides in the fact that structural choices in the development path need not repeat every time the structure changes. Initial structural patterns spread in the development system and form the final structure. However, when a certain development path is chosen, it is very difficult to change its direction.

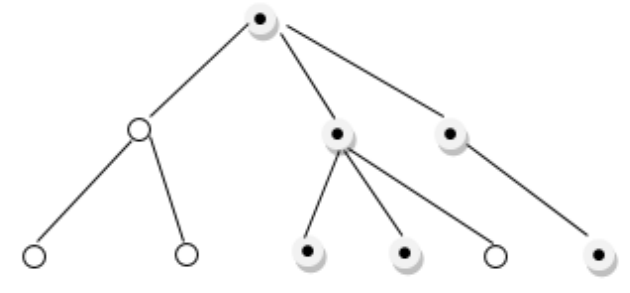

- Original property

Modified property

Figure 4. Generative entrenchment. "Language processing and second language development: Processability theory.

Studies in Bilingualism" by M. Rienemann, 1998, p. 317.

Pienemann and Keßler (2012) point out the following important factors in their explanation of the Processability Theory:

a) Second language development progresses according to universal stages which are limited by the language processing hierarchy.

b) Variability of interlanguage is limited and regular, and the limitations and regularities happen according to the language processing hierarchy.

c) Transfer from the first language is limited by the ability to process a certain structure, that is, the forms from the first language can be transferred to the second language only when those forms can be processed within the system of the second language that is being developed.

d) Differences in tasks are limited by the language processing hierarchy. This assertion results in the Steadiness Hypothesis ${ }^{2}$ which claims that a certain interlanguage structure will be placed on the same developmental stage within different tasks as long as they relate to the same language processing ability level within language production.

e) Acquisition of both the first and second language is limited by the language processing hierarchy. However, both forms of acquisition may be related to different development paths.

f) Bilingual language development can be universally compared for different languages using the language processing hierarchy described in the PT.

\footnotetext{
1 The stated model comes from biology and philosophy and it was formed by Wimsatt (1986, 1991 in Pienemann, 1998) with its application to embryonic development of animals. Pienemann (1998) took it from biology and applied it to the development of language. The same way that the early development of an embryo is very important, early decisions in acquiring language are equally important, considering that they influence final development. It is very difficult, almost impossible, to change the development path after a decision has been made.

${ }^{2}$ To confirm the predictions stated in the Steadiness Hypothesis, Pienemann (1998) tested the interlanguage of six subjects by using the emergence criterion in morphology and syntax. All interlanguage patterns displayed perfect consistency for syntax, while the consistency of $99.1 \%$ was proven for morphology. Consistency is very important because of the testing for levels of processing and variability within grammatical principles. If the grammatical settings were to change depending on the situation, it would be impossible to test the predictions set out in PT.
} 
These statements are based on the language processing hierarchy, which is based on the universal system of processing tools that can be explained using lexical functional grammar and Hypothesis Space, which is based on the assertion that the structures which can be processed are limited on any level by the available processing tools.

The limitations of Hypothesis Space imposed by the PT concern the age differences in the process of second language acquisition. The basic question is what causes those differences, and if they are caused by two different acquisition processes, what is the true nature of those processes. Pieneman (1998) considers that Clahsen's (1985 in Pienemann, 1998) proposal is the most useful, which assumes that children have access to universal grammar and second language learners do not. According to Clahsen, the latter group uses language processing strategies instead of universal grammar.

Pienemann (1998) considers that grammar coding architecture must be constructed equally by children as well as second language learners, although he points out that there is a different development path for the acquisition of the first and the second language. There is no reason to believe that different language processing procedures are used by children and by second language learners. However, the claim that the PT can explain the direction of language acquisition in children and adults leaves many unanswered questions, primarily the following:

1) What is the basis for creating hypotheses in the first and the second language?

2) Which mechanisms affect the development of structures in the student's language?

These questions can be related to the point of view held by Clahsen and Meisel (1991, in Pienemann, 1998), which says that first language learners create more effective hypotheses than second language students and are more successful in controlling them.

The following Tables (2 and 3) provide the complete overview of interlanguage research based on Processability Theory.

Table 2. Overview of the interlanguage researches based on Processability Theory from 1996 to 2004 (according to Pienemann, 2005b:61-65)

\begin{tabular}{|c|c|c|c|}
\hline Researcher/Year & Language & Structure & Results \\
\hline Fetter (1996) & English & Morphosyntax & $\begin{array}{l}\text { Does not confirm PT as there are a lot } \\
\text { of patterns missing in the implicational } \\
\text { scaling }\end{array}$ \\
\hline $\begin{array}{l}\text { Pienemann \& Hakansson } \\
\text { (1999) }\end{array}$ & Swedish & Morphosyntax & Confirmation of PT \\
\hline Bartning (2000) & French & Morphology and syntax & $\begin{array}{l}\text { Morphology is more systematic and } \\
\text { develops in a predictable way, unlike } \\
\text { syntax }\end{array}$ \\
\hline $\begin{array}{l}\text { Mansouri (2000, in } \\
\text { Pienemann, 2005b) }\end{array}$ & Arabic & Morphology and syntax & Confirmation of PT \\
\hline Devaele \& Veronique (2001) & French & $\begin{array}{l}\text { French adjectives in } \\
\text { gender assignment }\end{array}$ & $\begin{array}{l}\text { PT is not suitable for this kind of } \\
\text { research }\end{array}$ \\
\hline Glahn et al (2001) & $\begin{array}{l}\text { Scandinavian } \\
\text { languages }\end{array}$ & $\begin{array}{l}\text { Morphology } \\
\text { Syntax }\end{array}$ & Confirmation of PT \\
\hline $\begin{array}{l}\text { Hakansson, Salameh \& } \\
\text { Nettelblatt (2003) }\end{array}$ & $\begin{array}{l}\text { Swedish and French } \\
\text { acquisition in bilingual } \\
\text { children }\end{array}$ & Morphology & Confirmation of PT \\
\hline $\begin{array}{l}\text { Di Biase \& Kawaguchi } \\
\text { (2002) }\end{array}$ & $\begin{array}{l}\text { Japanese } \\
\text { Italian }\end{array}$ & Morphosyntax & Confirmation of PT \\
\hline $\begin{array}{l}\text { Iwasaki (2003, in } \\
\text { Pienemann, 2005b) }\end{array}$ & Japanese & Morphosyntax & Confirmation of PT \\
\hline
\end{tabular}




\begin{tabular}{|c|c|c|c|}
\hline $\begin{array}{l}\text { Gao (2004, in Pienemann, } \\
2005 b)\end{array}$ & Mandarin & $\begin{array}{l}\text { Key grammatical } \\
\text { morphemes }\end{array}$ & $\begin{array}{l}\text { Confirmation of PT; Firm empirical } \\
\text { evidence against transfer in initial } \\
\text { stages of acquisition }\end{array}$ \\
\hline $\begin{array}{l}\text { Harada (2004, in } \\
\text { Pienemann, 2005b) }\end{array}$ & English & Acquisition of modality & $\begin{array}{l}\text { In the early stages of learning, only } \\
\text { lexical modality appears, whereas the } \\
\text { appearance of modal verbs is in } \\
\text { accordance with the appearance of a } \\
\text { verb phrase }\end{array}$ \\
\hline $\begin{array}{l}\text { Ozdemir (2004, in } \\
\text { Pienemann, 2005b) }\end{array}$ & $\begin{array}{l}\text { Turkish, German and } \\
\text { English acquisition in } \\
\text { trilingual children }\end{array}$ & 1 & Confirmation of PT \\
\hline $\begin{array}{l}\text { Taylor (2004, in Pienemann, } \\
2005 b)\end{array}$ & Spanish & Sentence structure & Confirmation of PT \\
\hline
\end{tabular}

Table 2 shows that recent research confirmed the PT; in other words, certain structures appear in the predicted order. The research of agreement in French adjectives focusing on levels of accuracy in grammatical gender is the exception, because according to lexical-functional grammar, the grammatical gender is a lexical feature and must be acquired individually for each lexical item, therefore, the ability to transfer grammatical information at the PT level can only be tested if the grammatical gender is determined for each unit in the learner's lexicon. Fetter's (1996) research also does not confirm the PT, because it concludes that implicational scaling lacks certain patterns.

Table 3. The latest interlanguage researches based on Processability Theory

\begin{tabular}{|c|c|c|c|}
\hline Researcher/Year & Language & Structure & Results \\
\hline Kawaguchi (2005) & Japanese & Syntax & Confirmation of PT \\
\hline Mansouri (2005) & Arabic & $\begin{array}{l}\text { Morphology and } \\
\text { syntax }\end{array}$ & Confirmation of PT \\
\hline Zhang (2005) & Chinese & $\begin{array}{l}5 \text { grammatical } \\
\text { morphemes }\end{array}$ & $\begin{array}{l}\text { Morphemes are acquired in a predicted order proposed by } \\
\text { PT }\end{array}$ \\
\hline $\begin{array}{l}\text { Mansouri \& Duffy } \\
\text { (2005) }\end{array}$ & English & Syntax & $\begin{array}{l}\text { Confirmation of PT } \\
\text { - research of syntax in English as the second language } \\
\text { shows that learners exposed to instruction in accordance } \\
\text { with the developmental order predicted in PT produce the } \\
\text { target language structures with a higher grammatical } \\
\text { accuracy than those exposed to the reversed order }\end{array}$ \\
\hline $\begin{array}{l}\text { Dao }(2007, \text { in } \\
\text { Charters, Dao \& } \\
\text { Jansen) }\end{array}$ & English & $\begin{array}{l}\text { Inflections in lexical } \\
\text { and phrasal contexts }\end{array}$ & $\begin{array}{l}\text { As opposed to PT, inflexions emerge in phrasal contexts } \\
\text { prior to inflexions in lexical contexts }\end{array}$ \\
\hline $\begin{array}{l}\text { Hakansson \& } \\
\text { Norrby }(2007 \text {, in } \\
\text { Hakansson, 2013) }\end{array}$ & Swedish & $\begin{array}{l}\text { Written and oral } \\
\text { production }\end{array}$ & Confirmation of PT \\
\hline Philipsson (2007) & Swedish & $\begin{array}{l}\text { Questions and verb } \\
\text { morphology }\end{array}$ & $\begin{array}{l}\text { Grammaticality judgement tests show that the structures } \\
\text { testing declarative knowledge, unlike procedural, are not } \\
\text { acquired according to the predictions of PT }\end{array}$ \\
\hline Ellis (2008) & English & $\begin{array}{l}\text { Grammatical } \\
\text { structures }\end{array}$ & $\begin{array}{l}\text { Grammaticality judgement tests show that the structures } \\
\text { testing declarative knowledge, unlike procedural, are not } \\
\text { acquired according to the predictions of PT }\end{array}$ \\
\hline Jansen (2008) & German & $\begin{array}{l}\text { Cross-sectional study } \\
\text { of the German word } \\
\text { order }\end{array}$ & Confirmation of PT \\
\hline $\begin{array}{l}\text { Rahkonen \& } \\
\text { Hakansson (2008, }\end{array}$ & Swedish & $\begin{array}{l}\text { Lexical morphology, } \\
\text { Phrasal morphology, }\end{array}$ & $\begin{array}{l}\text { The structures emerge according to the predicted order; } \\
\text { lexical and phrasal morphology emerge first, followed by }\end{array}$ \\
\hline
\end{tabular}


in Hakansson, 2013)

\begin{tabular}{|c|c|c|}
\hline Sakai (2008) & English & $\begin{array}{l}\text { subordinate clause } \\
\text { Questions, word o } \\
\text { negation }\end{array}$ \\
\hline $\begin{array}{l}\text { Alhawary }(2009 \text {, as } \\
\text { cited in Bonilla, } \\
2012)\end{array}$ & Arabic & Morphosyntax \\
\hline $\begin{array}{l}\text { Heinonen (2009) } \\
\text { Researcher/Year }\end{array}$ & $\begin{array}{l}\text { Swedish } \\
\text { Language }\end{array}$ & $\begin{array}{l}\text { Morphosyntax } \\
\text { Structure }\end{array}$ \\
\hline Dyson (2009) & English & $\begin{array}{l}\text { Morphology and } \\
\text { syntax }\end{array}$ \\
\hline Medojević (2009) & Serbian & $\begin{array}{l}\text { Morphology and } \\
\text { syntax }\end{array}$ \\
\hline Dyson (2011) & English & $\begin{array}{l}\text { Morphology and } \\
\text { syntax }\end{array}$ \\
\hline $\begin{array}{l}\text { Hakansson \& } \\
\text { Norrby (2010) }\end{array}$ & Swedish & $\begin{array}{l}\text { Grammar, pragma } \\
\text { lexicon }\end{array}$ \\
\hline $\begin{array}{l}\text { Schönström (2010, } \\
\text { in Hakansson, } \\
\text { 2013) }\end{array}$ & Swedish & $\begin{array}{l}\text { Written production } \\
\text { deaf learners; } \\
\text { Lexical, phrasal an } \\
\text { inter-phrasal struc }\end{array}$ \\
\hline $\begin{array}{l}\text { Zhang \& Widyastuti } \\
(2010)\end{array}$ & English & Morphology \\
\hline Baten (2011) & German & German case syst \\
\hline $\begin{array}{l}\text { Charters, Dao \& } \\
\text { Jansen (2011) }\end{array}$ & English & Plural marking \\
\hline $\begin{array}{l}\text { Itani-Adams (2011, } \\
\text { in Pienemann and } \\
\text { Keßler, 2011) }\end{array}$ & $\begin{array}{l}\text { Japanese; } \\
\text { English }\end{array}$ & $\begin{array}{l}\text { Morphology and } \\
\text { syntax }\end{array}$ \\
\hline Spinner (2011) & English & $\begin{array}{l}\text { Morphosyntax in } \\
\text { productive tasks }\end{array}$ \\
\hline Doman (2012) & English & $\begin{array}{l}\text { Syntax (relative } \\
\text { clauses) }\end{array}$ \\
\hline Bonilla (2012) & Spanish & $\begin{array}{l}\text { Morphology and } \\
\text { syntax }\end{array}$ \\
\hline
\end{tabular}

morphology,

Inversion in main

clauses, the word order in subordinate clause

Cancel inversion in

subordinate clauses,

Pre-verbal negation in
subordinate clauses

Confirmation of $P$

L2 learners of Arabic with L1 English and French learning Arabic as a foreign language in their home countries did not show simultaneous emergence of stage 4 (gender and verb agreement)

Confirmation of PT

Results

The study found the acquisition of structures both predicted and not predicted by PT (acquisition of morphology, and syntax varies with learner orientation)

Confirmation of PT

Confirmation of PT

Confirmation of PT

Confirmation of PT

Confirmation of PT

Confirmation of PT

The study shows certain flaws of PT, as it is based on implicit assumptions which cannot be applied to some other first or second languages and, therefore, lead to wrong predictions; transfer from the first language is in accordance with the developmentally moderated transfer ${ }^{1}$ explained in the PT

Both languages developed in a predicted order proposed by PT, but not simultaneously; both languages had their own, individual path

Implicational scaling based on the Rapid Profile software showed that structures are acquired according to predictions presented in $\mathrm{PT}$

Confirmation of Pienemann's Teachability Hypothesis

Confirmation of PT;

The results question the main claim of the Teachability Hypothesis that instruction only focused on the next stage can accelerate the natural acquisition process - the

${ }_{1}^{1}$ Pienemann (2005b) states that transfer from the first language is developmentally moderated, meaning that it will occur when the structure to be transferred is processable withing the developing system of the second language. 


\begin{tabular}{|c|c|c|c|}
\hline & & & $\begin{array}{l}\text { results showed that learners were able to acquire not only } \\
\text { the next stage, but the following stage too }\end{array}$ \\
\hline Bonilla (2014) & Spanish & $\begin{array}{l}\text { Morphology and } \\
\text { syntax }\end{array}$ & Confirmation of PT \\
\hline $\begin{array}{l}\text { Tang \& Zhang } \\
\text { (2015) }\end{array}$ & English & $\begin{array}{l}\text { Written and oral } \\
\text { production }\end{array}$ & $\begin{array}{l}\text { Confirmation of PT; learners are more successful in } \\
\text { written than in oral testing }\end{array}$ \\
\hline Researcher/Year & Language & Structure & Results \\
\hline $\begin{array}{l}\text { Zhang \& Lantolf } \\
\text { (2015) }\end{array}$ & Chinese & $\begin{array}{l}\text { Topicalization in the } \\
\text { Chinese language }\end{array}$ & $\begin{array}{l}\text { It is possible to artificially construct a developmental route } \\
\text { different from the one predicted by natural developmental } \\
\text { sequences }\end{array}$ \\
\hline
\end{tabular}

Table 3 shows that most of the structures are acquired according to the schedule predicted by the PT, aside from the tests where the criteria are implicit ${ }^{1}$ (procedural) and explicit ${ }^{2}$ (declarative) knowledge (Philipssson, 2007; Ellis, 2008). The tests that measured implicit knowledge showed in both cases that the structures are acquired according to implicational scaling elaborated in the PT, while the grammatical assessment tests that measured explicit knowledge showed that acquisition does not take place according to the predicted schedule. Research done by Dao (2007) also does not confirm the PT because contrary to the PT, inflections emerge first in phrasal and then in lexical contexts. Dyson's (2009) research partly disproves the PT, considering that stages 3 and 4 developed before morphology in syntax. Dyson uses the fact that the properties of universal grammar encourage syntactic development in stages, which is interacting with the morphological properties proposed in the PT, to explain this. The application of the PT to the Arabic language did not answer the question why students acquire different structures at a different pace if the structures can be processed (Alhawary 2009, in Bonilla, 2012). Research by Charters, Dao, and Jansen (2011) confirms the PT in the part concerning transfer from the first language, which develops according to the developmentally moderated transfer hypothesis, but it also shows certain deficiencies in the PT, considering that it is based on implicit assumptions which may not be valid for some first or second languages and because of that they result in incorrect predictions. It is interesting that Medojevic (2009) worked on the application of the PT on the Serbian language, which is actually the first time it was applied on any Slavic language. She applied the stated theory by testing three teenagers who live in Australia and speak Serbian at home. Her research confirmed the PT. Therefore, the stated theory can also be applied to the Serbian Language.

As is evident from tables 2 and 3 it is possible to predict the second language path by applying PT not only to English, but to other languages too.

\section{Conclusion}

By investigating developmental patterns, one can get a closer insight into the development of the learner's interlanguage. Since developmental stages can be predicted in advance, a conclusion that interlanguage develops in a regular, predictable way can be drawn. However, it is important to describe and determine developmental stages in advance in order to adjust teaching to the learner's present developmental stage. It is therefore important to introduce the teachers to the notion of interlanguage and developmental stages in order to observe the factors that hinder or facilitate their learner's progress applying an individualized approach to each learner while at the same time observing the changes in the learner's interlanguage on his/her way of mastering the second language. Observing the developmental path of the student's interlanguage removes thus the focus from describing and counting errors and makes us understand that errors are to be

\footnotetext{
${ }^{1}$ Ellis (2008) defines implicit knowledge as intuitive, procedural, systematic, receptive to changes, automatic, and therefore available for fluid, unplanned use of language. It is not receptive to verbalization. It is considered that it can be learned only until the critical period (puberty).

${ }^{2}$ According to Ellis (2008) explicit knowledge is conscious, declarative, irregular, and inconsistent, and it can only be accessed through controlled processing and planned use of language. It can be verbalised and in that case it includes technical metalanguage. It can be learned at any age.
} 
expected in the development of the learner's second language and that they are, in fact, indicators of progress, so interlanguage should be viewed as the linguistic potential that needs to be additionally explored and utilised in the future.

\section{References}

[1] Baten, K. (2011). Processability Theory and German Case Acquisition. Language Learning, 61 (2), 455-505.

[2] Bley-Vroman, R. (1983). The Comparative Fallacy in Interlanguage Studies: The Case of Systematicity. Language Learning, 33 (1), 1-17.

[3] Bonilla, C.L. (2012). Testing Processability Theory in L2 Spanish: Can Readiness or Markedness Predict Development

[4] (Doctoral thesis, University of Pittsburgh, USA). Retrieved from http://dscholarship.pitt.edu/11611/1/BonillaCL_2012.pdf.

[5] Bonilla, C.L. (2014). From number agreement to the subjunctive: Evidence for Processability Theory in L2 Spanish. Second Language Research, 1-22.

[6] Brown, R. (1973). A First Language: The first Stages. London: George Allen \& Unwin Ltd.

[7] Charters, H., Dao, L. \& Jansen, L. (2011). Reassessing the applicability of Processing Theory: The case of nominal plural. Second Language Research, 27 (4), 509-533.

[8] Corder, S.P. (1967). The significance of learners' errors. IRAL, 10 (4), 159-170.

[9] Decamp, D. (1971). Implicational Scales and Sociolinguistic Linearity. Linguistics, 17, 79-106.

[10] Doman, E. (2012). Further Evidence for the Developmental Stages of Language Learning and Processability. US-China Education Review, 2 (9), 813-825.

[11] Dulay, H. \& Burt, M. (1974). Errors and Strategies in Child Second Language Acquisition. TESOL Quarterly, 8 (2), 128-136.

[12] Dyson, B. (2009). Processability theory and the role of morphology in English as a second language development: a longitudinal study. Second Language Research, 25 (3), 355-376.

[13] Dyson, B. (2010). Learner Language Analytic Methods and Pedagogical Implications. Australian Review of Applied Linguistics, 33 (3), 30.1-30.21.

[14] Ellis, R. (1994). The Study of Second Language Acquisition. Oxford: Oxford University Press.

[15] Ellis, R. (2008). Investigating grammatical difficulty in second language learning: Implications for second language acquisition research and language testing. International Journal of Applied Linguistics, 18 (1), 4-22.

[16] Garcia Mayo, M. Junkal Gutierrez Mangado, M., Martinez Adrian, M. (Eds.) (2013). Contemporary Approaches to Second Language Acquisition. Amsterdam/Philadelphia: John Benjamins Publishing Company.

[17] Gass, S. \& Mackey, A. (Eds.) (2012). The Routledge Handbook of Second Language Acquisition. New York and London: Routledge. Taylor\&Francis Group.

[18] Hakansson, G. \& Norrby, C. (2010). Environmental influence on language acquisition: Comparing second and foreign language acquisition of Swedish. Language Learning, 60 (3), 628-650.

[19] Hakansson, G. (2013). Processability Theory. Explaining developmental sequences. In M. Garcia Mayo, M. Junkal Gutierrez Mangado \& M. Martinez Adrian (Eds.), Contemporary Approaches to Second Language Acquisition (pp. 111-129). Amsterdam/Philadelphia: John Benjamins Publishing Company. 
[20] Han, Z.-H. \& Tarone, E. (Eds.) (2014). Interlanguage: Forty years later. Amsterdam/Philadelphia. John Benjamins Publishing Company.

[21] Heinonen, E.M. (2009). Processbarhet på prov Bedömning av muntlig språkfärdighet hos vuxna andraspråksinlärare (Unpublished doctoral thesis, Uppsala Universitet, Sweden). Retrieved from http://uu.divaportal.org/smash/get/diva2:173105/FULLTEXT01.pdf.

[22] Jansen, L. (2008). Acquisition of German Word Order. Language Learning, 58 (1), 185-231.

[23] Kawaguchi, S. (2005). Argument structure and syntactic development in Japanese as a second language. In M. Pienemann (Eds.), Cross-linguistic aspects of processability theory (pp. 253-299). Amsterdam/Philadelphia: John Benjamins Publishing Company.

[24] Keßler, J-U. \& Keatinge, D. (Eds.) (2009). Research in Second Language Acquisition: Empirical Evidence across Languages. Newcastle upon Tyne: Cambridge Scholars Publishing.

[25] Lowie, W. \& Verspoor, M. (2015). Variability and Variation in Second Language Acquisition Orders: A Dynamic Reevaluation. Language Learning, 65 (1), 63-88.

[26] Mansouri, F. (2005). Agreement morphology in Arabic as a second language. In M. Pienemann (Eds.), Crosslinguistic aspects of processability theory (pp. 117-155). Amsterdam/Philadelphia: John Benjamins Publishing Company.

[27] Medojević, L. (2009). Applying Processability Theory and Its Extension to Serbian as a Family and Community Language in Australia. In J-U. Keßler \& D. Keatinge (Eds.), Research in Second Language Acquisition: Empirical Evidence across Languages (pp. 267-293). Newcastle upon Tyne: Cambridge Scholars Publishing.

[28] Ortega, L (2014). Trying out theories on interlanguage: Description and explanation over 40 years of $L 2$ negation research. In Z.-H. Han \& E. Tarone (Eds.), Interlanguage: Forty years later (pp. 179-203). Amsterdam/Philadelphia. John Benjamins Publishing Company.

[29] Pallotti, G. (2010). Doing interlanguage analysis in school context. In I. Bartning, M. Martin \& I. Vedder (Eds.), Communicative proficiency and linguistic development: intersections between SLA and language testing research (pp. 159-191). European second language association 2010.

[30] Pica, T. (1983). Adult Acquisition of English as a Second Language Under Different Conditions of Exposure. Language Learning, 33 (4), 465-497.

[31] Pienemann, M. (1998). Language processing and second language development: Processability theory. Studies in Bilingualism. Amsterdam: John Benjamins Publishing Company.

[32] Pienemann, M. (Eds.) (2005). Cross-linguistic aspects of processability theory. Amsterdam/Philadelphia: John Benjamins Publishing Company.

[33] Pienemann, M. (2005b). An introduction to Processability Theory. In M. Pienemann (Eds.), Cross-linguistic aspects of processability theory (pp.61-85). Amsterdam/Philadelphia: John Benjamins Publishing Company.

[34] Pienemann, M. \& Keßler, J.-U. (2011). Studying Processability theory: An introductory textbook. Amsterdam: John Benjamins Publishing company.

[35] Pienemann, M. \& Keßler, J.-U. (2012). Processability theory. In S. Gass \& A. Mackey (Eds.), The Routledge Handbook of Second Language Acquisition (pp. 228-247). New York and London: Routledge. Taylor\&Francis Group.

[36] Philipsson, A. (2007). Interrogative Clauses and Verb Morphology in L2 Swedish: Theoretical Interpretations of Grammatical Development and Effects of Different Elicitation Tehniques (Doctoral thesis, Stockholm University, Sweden). Retrieved from http://www.diva-portal.org/smash/get/diva2:197193/FULLTEXT01.pdf.

[37] Sakai, H. (2008). An analysis of Japanese university students' oral performance in English using processability theory. Elsevier System, 36 (4), 534-549. 
[38] Selinker, L. (1972). Interlanguage. IRAL, 10 (3), 209-231.

[39] Spinner, P. (2011). Second Language Assessment and Morphosyntactic Development. Studies in Second Language Acquisition, 33, 529-561.

[40] Tang, H. \& Zhang, Y. (2015). An Investigation of Chinese Students' Acquisition of Oral and Written English through the Measurement of Processability Theory. International Journal of Apllied Linguistics \& English Literature, 4 (2), 207-211.

[41] Tarone, E. (1983). On the Variability of Interlanguage Systems. Applied Linguistics, 4 (2), 142-164.

[42] Zhang, X. \& Latolf, J.P. (2015). Natural or Artificial: Is the Route of L2 Development Teachable? Language Learning, 65 (1), 152-180. 